\title{
Synthesis and Photophysical Properties of Rhenium(I)-alkynyl Molecular Rectangles
}

\section{ARUMUGAM RAMDASS ${ }^{1}$, VEERASAMY SATHISH ${ }^{2}$, BALA. MANIMARAN ${ }^{3 *}$, POUNRAJ THANASEKARAN ${ }^{4}$ and SEENIVASAN RAJAGOPAL ${ }^{5,6 *}$}

${ }^{1}$ Research Department of Chemistry, Aditanar College of Arts and Science,

Tiruchendur - 628 216, India.

${ }^{2}$ Department of Chemistry, Bannari Amman Institute of Technology, Sathyamangalam, India.

${ }^{3}$ Department of Chemistry, Pondicherry University, Puducherry - 605 014, India .

${ }^{4}$ Institute of Chemistry, Academia Sinica, Taipei - 115, Taiwan.

${ }^{5}$ School of Chemistry, Madurai Kamaraj University, Madurai - 625 021, India.

${ }^{6}$ Present Address: Postgraduate and Research Department of Chemistry, Vivekananda College,

Tiruvedagam West - 625 234, Madurai, India.

${ }^{*}$ Corresponding author E-mail: manimaran.che@ pondiuni.edu.in

http://dx.doi.org/10.13005/ojc/320413

(Received: May 12, 2016; Accepted: July 27, 2016)

\begin{abstract}
A series of highly conjugated, rigid $\operatorname{Re}(\mathrm{I})$-based molecular rectangles $\left\{\left[\text { fac- } \operatorname{Re}(\mathrm{CO})_{3} \mathrm{Br}\right]_{2}(\mu\right.$-bpy) $(\mu \text {-L) }\}_{2}(1, L=1,4$-bis(42 -pyridylethynyl)benzene, bpeb; $2, L=1,4$-bis(42 -pyridylethynyl)naphthalene, bpen; $3, L=1,4$-bis(42 -pyridylethynyl)anthracene, bpea; and bpy = 4,42 -bipyridine) containing two different types of pyridyl ligands were synthesized, characterized and their photophysical properties studied. Successful emission color tuning was achieved by incorporating rigid alkynyl ligands into the $\operatorname{Re}(\mathrm{I})$ rectangles. Complexes 1-3 exhibited an intense absorption bands with a high e value at $>340$ $\mathrm{nm}$ in THF solution, which is attributed to mixed two metal-to-ligand charge transfer $\mathrm{d} \pi(\mathrm{Re}) \rightarrow \pi^{*}(\mathrm{bpy})$ and $\mathrm{d} \pi(\operatorname{Re}) \rightarrow \pi^{\star}($ alkynyl)) along with ligand-to-ligand charge transfer ('LLCT)/ and intraligand charge transfer ( ${ }^{1} \mathrm{ILCT}$ ) transitions. Compound 1 featured a broad and structureless emission band at 619 $\mathrm{nm}$, which was attributed to the emission of ${ }^{3} \mathrm{MLCT} d \pi(\mathrm{Re}) \rightarrow \pi^{*}(\mathrm{bpy})$ and/or $\left[\mathrm{d} \pi(\mathrm{Re}) \rightarrow \pi^{*}(\right.$ alkynyl)] characteristics with an additional luminescence at $431 \mathrm{~nm}$. Whereas complexes 2 and $\mathbf{3}$ displayed an intraligand (IL) emission at 445 and 489 (sh), $521 \mathrm{~nm}$. These compounds represent a new class of visible light-harvesting materials that exhibit greatly enhanced emission decay lifetimes as a result of intervening ligand triplet states $\left({ }^{3}\right.$ LLCT/3ILCT) present on the alkynyl appended naphthalene and anthracene chromophores, as evidenced by transient absorption spectra.
\end{abstract}

Keywords: Rectangles, alkynyl ligands, luminescence, quenching, rhenium. 


\section{INTRODUCTION}

In the natural photosynthetic apparatus, energy is harvested by antenna pigments and transferred into a reaction center where charge separation takes place ${ }^{1,2}$. Since the natural lightharvesting system contains a larger number of different chromophores, the artificial antennae require an ingenious molecular design that allows the incorporation of a number of different chromophore units and their efficient cooperation with one another, as well as acquiring light energy over a long distance to a designated unit. To mimic the antenna function, chemists have attempted to prepare different types of artificial systems ${ }^{3-10}$. Metallocyclophanes are of special interest since multiple chromophoric ligands can be incorporated into this system as found in photosynthetic reaction centers ${ }^{8-10}$. As for an elegant example, Wurthner and co-workers ${ }^{10}$ demonstrated that a $\mathrm{Pt}(\mathrm{II})$-based molecular square containing sixteen pyrene chromophores constitutes a lightharvesting system that undergoes the combination of rapid energy and efficient electron transfer processes.

Different from bimolecular complexes ${ }^{3-7}$ and molecular squares, ${ }^{8-10}$ rectangles contain two types of different chromophore units in the peripheral environments. In addition, transition metal-alkynyl compounds with a conjugated p-system have been a topic of rapidly growing interest as a result of their unique photo physical properties ${ }^{11-14}$. Yam and coworkers ${ }^{15}$ reported that the luminescence behavior of a rhenium(I) chromophore is perturbed by $-\mathrm{C} \equiv \mathrm{C}$ - units. In addition, the alkynyl ligand exhibits an excellent conduit for electron transport, thereby facilitating fast intramolecular electron and energy exchange between the various subunits. With the objective of achieving desirable artificial antenna, we herein designed and synthesized a series of highly conjugated and rigid $\operatorname{Re}(\mathrm{I})$-based molecular rectangles 1-3 containing two different types of bidentate pyridyl ligands. As shown in Chart 1 , one of the ligand units is comprised of phenylene, naphthalene and anthracene, which is then connected by pyridyl ligands via an ethynyl spacer, forming the composite complexes 1, 2 and 3 , respectively. Details are elaborated in the following section.

\section{MATERIALS AND METHODS}

\section{Materials}

Reagents were used as received. All manipulations were performed under a nitrogen atmosphere using standard Schlenk techniques. Chromatographic separation could be done in air. Tetrahydrofuran was dried over $\mathrm{CaH}_{2}$ and was freshly distilled prior to use. Compounds 1 , 4-bis(4'-pyridylethynyl)benzene (bpeb), 1,4-bis (4'-pyridylethynyl)naphthalene (bpen) and 1,4-bis (4'-pyridylethynyl)anthracene (bpea) were synthesized by published methods ${ }^{16-18}$. The details of the synthesis of 1 have already been published ${ }^{19,20}$.

\section{Instrumentation}

IR spectra were recorded on a Perkin Elmer 882 FT-IR spectrophotometer and NMR spectra on a AMX-400 FT-NMR spectrometers. Elemental analyses were performed using a Perkin-Elmer $2400 \mathrm{CHN}$ elemental analyzer. UV-visible spectra were obtained on a Hewlett Packard-8453 spectrophotometer at room temperature in 1-cm quartz cell. Fluorescence spectra were collected by means of a Hitachi F-4500 Fluorescence spectrophotometer. Luminescence decay measurements were performed with an Edinburgh single-photon counting instrument. The flash photolysis apparatus for the measurement of transient absorption spectra in the nanosecond time domain has been described elsewhere ${ }^{21}$. The excitation wavelength of $355 \mathrm{~nm}$ from a Nd:YAG laser (Continuum Surlite II, third harmonic) was used as the excitation source, coupled with a fast response photomultiplier (Hamamatsu model R5509-72) operated at $-80^{\circ} \mathrm{C}$ in nanosecond flash photolysis experiments (pulse width ca. 8 ns and energy 50 $\mathrm{mJ}$ per pulse). Transient spectra were obtained by a point-to-point technique, monitoring the absorbance changes $(\Delta \mathrm{A})$ after flash at intervals of $10 \mathrm{~nm}$ over the spectral range $300-700 \mathrm{~nm}$, averaging at least 30 decays for each wavelength. The values (the time at which the initial signal is $t_{1 / 2}$ halved) are reported for transients showing second-order kinetics. Transient absorption signals were recorded using a laser flash photolysis system (Edinburgh LP920), in which an $\mathrm{Nd}$ :YAG laser (355 nm) pumped optical parametric oscillator and a white-light square pulse were used as the pump and probe beams, respectively. The temporal resolution was limited by an excitation pulse duration of $\sim 8 \mathrm{~ns}$. The low temperature emission 
spectra were taken using an Aminco Bowman series 2 luminescence spectrometer.

\section{Syntheses of Rhenium(I)-based Molecular Rectangles \\ Synthesis of $\left[\left\{\operatorname{Re}(\mathrm{CO})_{3}(\mathrm{I}-\mathrm{bpy}) \mathrm{Br}\right\}\left\{\operatorname{Re}(\mathrm{CO})_{3}(\mathrm{I}-\mathrm{bpen})\right.\right.$ $\mathrm{Br}\}]_{2}$ (2)}

To a solution of $\left\{\operatorname{ReBr}(\mathrm{CO})_{4}\right\}_{2}(\mu-b p y)^{22}(229$ $\mathrm{mg}, 0.25 \mathrm{mmol})$ in $\mathrm{CH}_{2} \mathrm{Cl}_{2}(200 \mathrm{~mL})$ and $\mathrm{CH}_{3} \mathrm{CN}$ $(1 \mathrm{~mL})$ at $5^{\circ} \mathrm{C}$ was added a solution of $\mathrm{Me}_{3} \mathrm{NO}$ (38 $\mathrm{mg}, 0.51 \mathrm{mmol})$ in $\mathrm{CH}_{2} \mathrm{Cl}_{2}(30 \mathrm{~mL})$. The reaction mixture was filtered through celite and the solvent was removed under vacuum and the residue was dissolved in $\mathrm{CH}_{2} \mathrm{Cl}_{2}(200 \mathrm{~mL})$. To a solution of $\left\{\operatorname{ReBr}(\mathrm{CO})_{3}(\mathrm{NCMe})\right\}_{2}\left(\mu\right.$-bpy) in $\mathrm{CH}_{2} \mathrm{Cl}_{2}$ a solution of 1,4-bis(4'-pyridylethynyl)naphthalene (bpen) $(91 \mathrm{mg}$, $0.30 \mathrm{mmol}$ ) in $\mathrm{CH}_{2} \mathrm{Cl}_{2}(250 \mathrm{~mL}$ ) was added slowly at $5^{\circ} \mathrm{C}$. When the completion of the reaction was shown by IR spectroscopy, the solvent was evaporated and the product was subjected to chromatographic separation on a silica gel column by use of a mixture of acetone and $\mathrm{CH}_{2} \mathrm{Cl}_{2}$ (1:99) as eluent to afford compound 2 (121 $\mathrm{mg}, 0.051 \mathrm{mmol}, 41 \%$ ) as a greenish yellow solid. IR $\left(\mathrm{CH}_{2} \mathrm{Cl}_{2}\right): \eta_{\mathrm{CO}} 2028$ (vs), 1929 (s), 1896 (s) cm $\mathrm{cm}^{-1}$; ${ }^{\mathrm{H}} \mathrm{NMR}$ (400 MHz, acetone$\left.d_{6}\right): \delta=9.07\left(\mathrm{~d},{ }^{3} \mathrm{~J}=6.8 \mathrm{~Hz}, \mathrm{H}^{3}, 8 \mathrm{H}\right.$, bpy), 8.91 (d, ${ }^{3} \mathrm{~J}=6.6 \mathrm{~Hz}, \mathrm{H}^{3}, 8 \mathrm{H}$, bpen), 8.48 (dd, ${ }^{3} \mathrm{~J}=6.4 \mathrm{~Hz},{ }^{4} \mathrm{~J}$ $=3.3 \mathrm{~Hz}, \mathrm{H}^{5}, 4 \mathrm{H}$, naphthyl, bpen), 8.05 (d, ${ }^{3} \mathrm{~J}=6.8$ $\mathrm{Hz}, \mathrm{H}^{2}, 8 \mathrm{H}$, bpen) 7.93 (s, $\mathrm{H}^{2}, 4 \mathrm{H}$, naphthyl, bpen), 7.79 (d, ${ }^{3} \mathrm{~J}=6.7 \mathrm{~Hz}, \mathrm{H}^{2}, 8 \mathrm{H}$, bpy), 7.73 (dd, ${ }^{3} \mathrm{~J}=6.4$ $\mathrm{Hz},{ }^{4} \mathrm{~J}=3.1 \mathrm{~Hz}, \mathrm{H}^{6}, 4 \mathrm{H}$, naphthyl, bpen); ${ }^{13} \mathrm{C}$ NMR (acetone-d $\mathrm{d}_{6}$ ): $\delta=192.4,196.7$ (s, 2:1, CO), 156.3 ( $\mathrm{C}^{3}$, bpy), 155.4 ( $\mathrm{C}^{3}$, bpen), 147.0 ( $\mathrm{C}^{1}$, bpy), 134.3 ( $\mathrm{C}^{1}$, bpen), 133.6 ( $\mathrm{C}^{4 \mathrm{a}}$, naphthyl, bpen), $132.0\left(\mathrm{C}^{2}\right.$, naphthyl, bpen), 129.4 ( $\mathrm{C}^{5}$, naphthyl, bpen), 128.6 ( $\mathrm{C}^{2}$, bpen), 127.2 ( $\mathrm{C}^{6}$, naphthyl, bpen), $124.8\left(\mathrm{C}^{2}\right.$, bpy), 122.0 ( $\mathrm{C}^{1}$, naphthyl, bpen), 95.5 ( $\mathrm{C}^{2}$, ethynyl, bpen), $93.5\left(\mathrm{C}^{1}\right.$, ethynyl, bpen); Anal. Calcd for $\mathrm{C}_{80}$ $\mathrm{H}_{44} \mathrm{~N}_{8} \mathrm{O}_{12} \mathrm{Br}_{4} \mathrm{Re}_{4} \cdot 2.5\left(\mathrm{CH}_{3} \mathrm{COCH}_{3}\right): \mathrm{C}, 42.05 ; \mathrm{H}, 2.22 ;$ N, 4.41. Found: C, 41.95; H, 1.99; N, 4.20.

\section{Synthesis of $\left[\left\{\operatorname{Re}(\mathrm{CO})_{3}(\mathrm{I}-\mathrm{bpy}) \mathrm{Br}\right\}\left\{\operatorname{Re}(\mathrm{CO})_{3}(\mathrm{I}-\mathrm{bpea})\right.\right.$ $\mathrm{Br}\}]_{2}$ (3)}

To a solution of $\left\{\operatorname{ReBr}(\mathrm{CO})_{4}\right\}_{2}$ ( $\mu$-bpy) (229 $\mathrm{mg}, 0.25 \mathrm{mmol})$ in $\mathrm{CH}_{2} \mathrm{Cl}_{2}(200 \mathrm{~mL})$ and $\mathrm{CH}_{3} \mathrm{CN}$ $(1 \mathrm{~mL})$ at $5^{\circ} \mathrm{C}$ was added a solution of $\mathrm{Me}_{3} \mathrm{NO}$ (38 $\mathrm{mg}, 0.51 \mathrm{mmol})$ in $\mathrm{CH}_{2} \mathrm{Cl}_{2}(30 \mathrm{~mL})$. The reaction mixture was filtered through celite and the solvent was removed under vacuum and the residue was dissolved in $\mathrm{CH}_{2} \mathrm{Cl}_{2}(200 \mathrm{~mL})$. To a solution of
$\left\{\operatorname{ReBr}(\mathrm{CO})_{3}(\mathrm{NCMe})\right\}_{2}$ (ì-bpy) in $\mathrm{CH}_{2} \mathrm{Cl}_{2}$ a solution of 1,4-bis(4'-pyridylethynyl)anthracene (bpea) (105 $\mathrm{mg}, 0.275 \mathrm{mmol})$ in $\mathrm{CH}_{2} \mathrm{Cl}_{2}(250 \mathrm{~mL})$ was added slowly at $5^{\circ} \mathrm{C}$. When the completion of the reaction was shown by IR spectroscopy, the solvent was evaporated and the product was subjected to chromatographic separation on a silica gel column by use of a mixture of acetone and $\mathrm{CH}_{2} \mathrm{Cl}_{2}(1: 99)$ as eluent to afford compound $3(118.7 \mathrm{mg}, 0.048$ $\mathrm{mmol}, 38 \%)$ as a bright red solid. IR $\left(\mathrm{CH}_{2} \mathrm{Cl}_{2}\right): \eta_{\mathrm{CO}}$ 2028 (vs), 1929 (s), 1894 (s) cm-1; ${ }^{1} \mathrm{H}$ NMR (400 $\mathrm{MHz}$, acetone- $\left.d_{6}\right): \delta=9.13\left(\mathrm{~d},{ }^{3} \mathrm{~J}=6.7 \mathrm{~Hz}, \mathrm{H}^{3}, 8 \mathrm{H}\right.$, bpy), 8.96 (d, ${ }^{3} J=6.6 \mathrm{~Hz}, \mathrm{H}^{3}, 8 \mathrm{H}$, bpea), 8.73 (dd, ${ }^{3} \mathrm{~J}=6.7 \mathrm{~Hz},{ }^{4} \mathrm{~J}=3.2 \mathrm{~Hz}, \mathrm{H}^{1}, 8 \mathrm{H}$, anthracenyl, bpea), $8.11\left(\mathrm{~d},{ }^{3} \mathrm{~J}=5.6 \mathrm{~Hz}, \mathrm{H}^{2}, 8 \mathrm{H}\right.$, bpea) $7.98\left(\mathrm{~d},{ }^{3} \mathrm{~J}=5.2\right.$ $\mathrm{Hz}, \mathrm{H}^{2}, 8 \mathrm{H}$, bpy), 7.74 (dd, ${ }^{3} \mathrm{~J}=6.7 \mathrm{~Hz},{ }^{4} \mathrm{~J}=3.2 \mathrm{~Hz}$, $\mathrm{H}^{2}, 8 \mathrm{H}$, anthracenyl, bpea); ${ }^{13} \mathrm{C}$ NMR (acetone- $\mathrm{d}_{6}$ ): $\delta=196.4,192.5$ (s, 2:1, CO), 156.4 (C $\left.{ }^{3}, \mathrm{bpy}\right), 155.5$ ( $\mathrm{C}^{3}$, bpea), 146.8 ( $\mathrm{C}^{1}$, bpy), 134.0 ( $\mathrm{C}^{1}$, bpea), 133.1 ( $\mathrm{C}^{\text {9a }}$, anthracenyl, bpea), 128.8 ( $\mathrm{C}^{2}$, bpea), 128.1 ( $\mathrm{C}^{1}$, anthracenyl, bpea), 127.5 ( $\mathrm{C}^{2}$, anthracenyl, bpea), 124.2 ( $\mathrm{C}^{2}$, bpy), 118.8 ( $\mathrm{C}^{9}$, anthracenyl, bpea), 100.0 ( $\mathrm{C}^{2}$, ethynyl, bpea), $94.2\left(\mathrm{C}^{1}\right.$, ethynyl, bpea); Anal. Calcd for $\mathrm{C}_{88} \mathrm{H}_{48} \mathrm{~N}_{8} \mathrm{O}_{12} \mathrm{Br}_{4} \mathrm{Re}_{4} \cdot\left(\mathrm{CH}_{3} \mathrm{COCH}_{3}\right)_{9}: \mathrm{C}$, 46.09; H, 3.43; N, 3.74. Found: C, 46.42; H, 2.99; N, 3.62.

\section{RESULTS AND DISCUSSION}

The new molecular rectangles $\left[\left\{\operatorname{Re}(\mathrm{CO})_{3}\right.\right.$ $(\mu$-bpy) $\mathrm{Br}\}\left\{\operatorname{Re}(\mathrm{CO})_{3}(\mu \text {-L)Br}\}\right]_{2}(2, \mathrm{~L}=1,4$-bis $(42$ -pyridylethynyl) naphthalene, bpen; 3, L = 1,4bis(42 -pyridylethynyl)anthracene, bpea) were synthesized by following the synthetic procedure similar to the 1 used for the synthesis of compound $\left[\left\{\operatorname{Re}(\mathrm{CO})_{3}(\mu \text {-bpy)Br}\}\left\{\operatorname{Re}(\mathrm{CO})_{3}(\mu-\mathrm{L}) \mathrm{Br}\right\}\right]_{2}(1, \mathrm{~L}=\right.$ 1,4-bis(42 -pyridylethynyl)benzene, bpeb) $)^{19,20}$. Characterization of the complexes 1-3 was achieved by a combination of elemental analyses, IR, ${ }^{1} \mathrm{H}$ and ${ }^{13} \mathrm{C}$ NMR spectroscopies. The ${ }^{1} \mathrm{H}$ NMR spectra for 2 and $\mathbf{3}$ are shown in Figs. S1 and S2, respectively.

\section{Absorption Spectra}

The UV-vis absorption spectra of 1-3 were recorded in THF solution (Table 1). The intense high-energy absorption bands (230-310 nm) are ascribed to an admixture of ligand centered (LC) $\pi \rightarrow \pi^{*}$ transitions of the bpy and alkynyl ligands as free ligands sit under these regions. Compared to the absorption bands of free ligands, the absorption 
bands in 1-3 are substantially red-shifted that could partially arise from the delocalization of both ligandcentered molecular orbitals due to the interaction with the $\operatorname{Re}(I) d \pi$ orbital. Based on our previous reports by considering the redox potentials of free bpy and alkynyl ligands ${ }^{19}$, we tentatively assigned the peak at $323 \mathrm{~nm}$ to $\operatorname{Re}(\mathrm{I}) \rightarrow$ bpy and $348 \mathrm{~nm}$ to $\operatorname{Re}(\mathrm{I}) \rightarrow$ alkynyl. With reference to spectroscopic studies on related rhenium(I) alkynyl complexes ${ }^{15,19,23-}$
${ }^{25}$ and free pyridyl and alkynyl ligands, the molar extinction coefficients in 1-3 at their lowest absorption band are found to be higher (in the order of $10^{4}$ $10^{5} \mathrm{dm}^{3} \mathrm{~mol}^{-1} \mathrm{~cm}^{-1}$ ) than that of typical $[\mathrm{d} p(\mathrm{Re}) \rightarrow$ $\left.p^{*}(\mathrm{~L})\right]$ MLCT transition (usually in the order of $10^{3}$ $\left.\mathrm{dm}^{3} \mathrm{~mol}^{-1} \mathrm{~cm}^{-1}\right)$. Hence, the absorption bands at 348, 385, and $465 \mathrm{~nm}$ for $1-3$, respectively, are assigned to the $\left[\mathrm{d} \pi(\mathrm{Re}) \rightarrow \pi^{\star}\right.$ (alkynyl)] metal-toligand charge transfer (MLCT) transition, mixed with

Table 1: Spectroscopic and photophysical data ${ }^{[a]}$

\begin{tabular}{|c|c|c|c|c|c|c|c|}
\hline Comp. & $\lambda_{\text {abs }}, \mathrm{nm}\left(\varepsilon_{\max }, \mathrm{dm}^{3} \mathrm{~mol}^{-1} \mathrm{~cm}^{-1}\right)$ & $\begin{array}{c}\lambda_{\max }^{\mathrm{em}} \\
\mathrm{nm}\end{array}$ & $\begin{array}{l}\tau_{\text {em }} \\
\text { ns }\end{array}$ & $\begin{array}{c}\phi_{\text {em }} \\
\left(\times 10^{-3}\right)^{[b]}\end{array}$ & $\begin{array}{c}k_{\mathrm{r}} \times 10^{3} \\
\mathrm{~s}^{-1}\end{array}$ & $\begin{array}{c}k_{\mathrm{nr}} \times 10^{6} \\
\mathrm{~s}^{-1}\end{array}$ & $\begin{array}{c}\lambda_{\max }^{\mathrm{em}} \\
\mathrm{nm}(77 \mathrm{~K})\end{array}$ \\
\hline bpeb & $229,318,377(\mathrm{sh})$ & $\begin{array}{c}346 \\
361(\mathrm{sh})\end{array}$ & 7.0 & 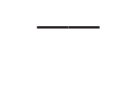 & 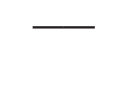 & $\longrightarrow$ & 367 \\
\hline bpen & $237,245,278,362,380(s h)$ & $\begin{array}{c}391 \\
412(\mathrm{sh})\end{array}$ & 4.8 & - & - & 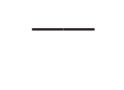 & 415 \\
\hline bpea & $230,273,309,438,465$ & $\begin{array}{l}474 \\
506\end{array}$ & 4.9 & 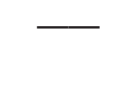 & - & - & 509 \\
\hline 1 & $\begin{array}{l}233 \text { (67 350), } 254 \text { (81 870), } \\
348 \text { (125 670) }\end{array}$ & $\begin{array}{l}431 \\
619\end{array}$ & 251 & 1.84 & 7.33 & 3.97 & $\begin{array}{c}542,574 \\
615(\mathrm{sh})\end{array}$ \\
\hline 2 & $\begin{array}{l}234 \text { (184 400), } 256 \text { (156 030), } \\
274(\mathrm{sh}), 385 \text { (132 800) }\end{array}$ & 445 & $\begin{array}{l}12.2 \\
13.0^{\text {[c] }}\end{array}$ & 0.54 & 44.3 & 82.0 & 417,468 \\
\hline 3 & $\begin{array}{l}233 \text { (158 510), } 242 \text { (sh), } 276 \\
(160 \text { 000), } 310 \text { (64 000), } 341 \\
(57 \text { 140), } 381(44340), 465 \\
(96400), 485 \text { (82 000) }\end{array}$ & $\begin{array}{l}489(\mathrm{sh}) \\
521\end{array}$ & $\begin{array}{l}27.0 \\
7.0^{[d]}\end{array}$ & 5.43 & 201 & 36.8 & 521,551 \\
\hline
\end{tabular}

[a]Data in deaerated THF solution at room temperature; [b]Standard: $\mathrm{Ru}(\mathrm{bpy})_{3}{ }^{2+}$ in $\mathrm{CH}_{3} \mathrm{CN}, \Phi_{\mathrm{em}}=0.062$ (J.M. Calvert, J.V. Casper, R.A. Binstead, T.D. Westmoreland, T.J. Meyer, J. Am. Chem. Soc. 104 (1982) 6620). ${ }^{[c]}$ $\lambda_{\text {max }}^{\mathrm{em}}=530 \mathrm{~nm} \cdot{ }^{[\mathrm{d}]} \lambda_{\text {max }}^{\mathrm{em}}=532 \mathrm{~nm}$.

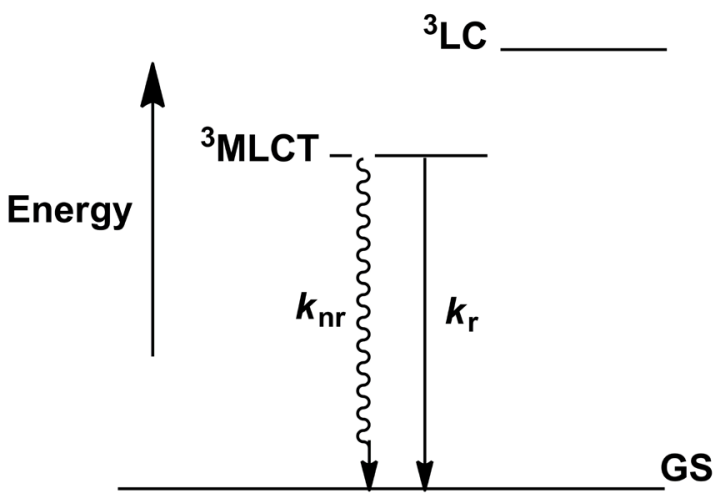

(a)

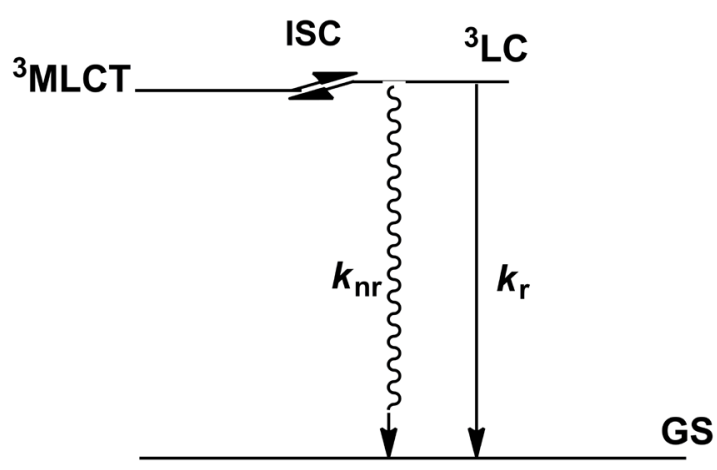

(b)

Scheme 1: Ground-state-excited-state energy scheme for

(a) ${ }^{3}$ MLCT emitter 1 and (b) ${ }^{3}$ LC emitters 2 and 3 
[ $\pi$ (alkynyl) $\rightarrow \pi^{*}$ (bpy)] ligand-to-ligand charge transfer (LLCT) and intraligand [ $\pi \rightarrow \pi^{\star}$ (alkynyl)] (IL) transitions (Fig. 1). Several rhenium(I)-bpy complexes with oligoether-appended coumarin (CM) ligands ${ }^{26}$ and pyridine containing macrocyclic phenylacetylene ligands $^{27}$ have been shown to exhibit two MLCT bands, which are attributed to $\mathrm{d} \pi(\mathrm{Re}) \rightarrow \pi^{\star}(\mathrm{bpy}-$ $\mathrm{CM}) / \mathrm{d} \pi(\mathrm{Re}) \rightarrow \pi^{\star}$ (alkynyl) and $\mathrm{d} \pi(\mathrm{Re}) \rightarrow \pi^{\star}($ bpy $) / \mathrm{d} \pi$ $(\mathrm{Re}) \rightarrow \pi^{\star}$ (alkynyl) MLCT bands, respectively.
Luminescence Spectra, Quantum Yields, and Lifetimes

All three complexes show luminescence upon excitation of their lowest absorption band. Emission color change from orange to blue and green in 1-3 mediated by the aryl substituents in the alkynylene, is observed for the first time. The blue shift in the emission maximum upon extending the p-conjugated system in these complexes represents an unusual phenomenon contradictory to the
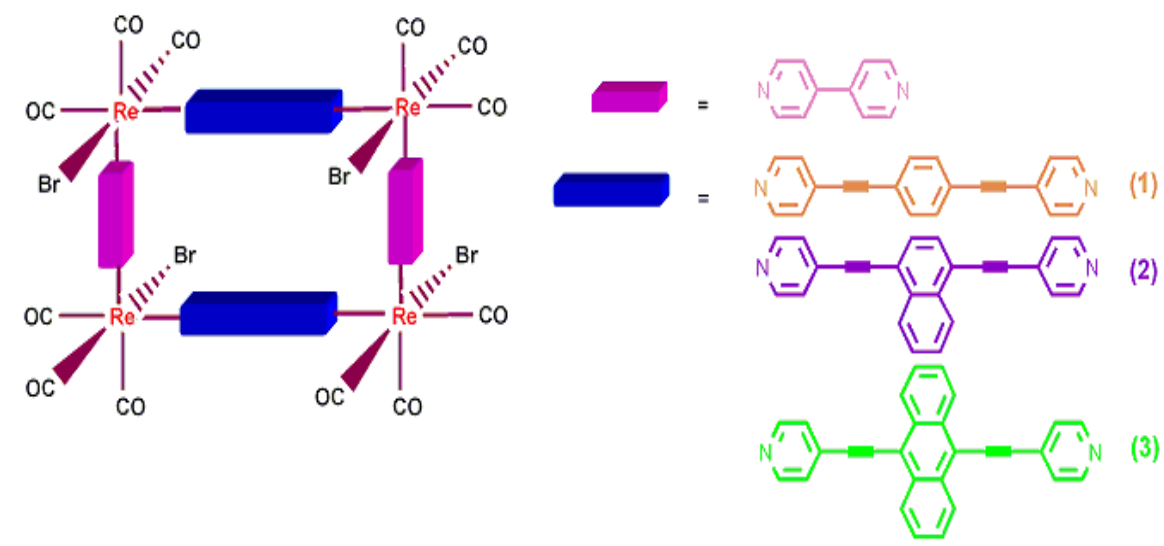

Chart 1: Structure of the complexes 1-3

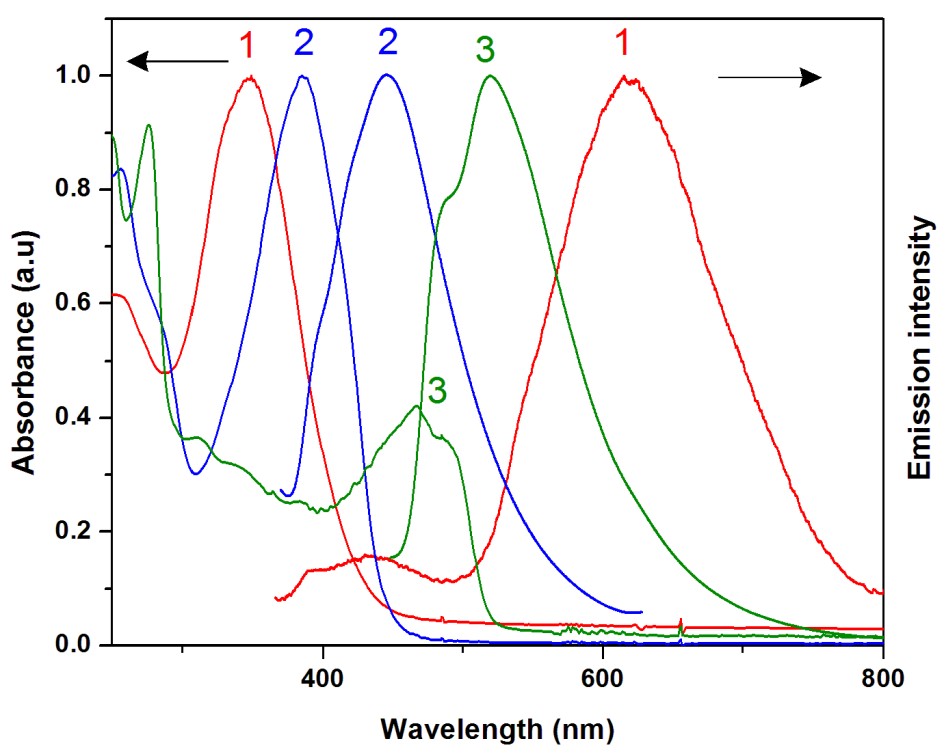

Fig. 1: Absorption and emission spectra of 1-3 $\left(6 \times 10^{-5} \mathrm{M}\right)$ in THF. For each compound, the excitation wavelength is picked at the maximum of the lowest lying absorption band 
common concept of tuning the emission maximum to the red shift via extended conjugation ${ }^{28,29}$. This is tentatively attributed to either different perturbations of the singlet and triplet MLCT states by the aryl substituents or the excited state structure is probably more polar than ground states ${ }^{30,31}$. The broad and structureless emission band of 1 at $619 \mathrm{~nm}$ features a combination of both $\left[\mathrm{d} \pi(\mathrm{Re}) \rightarrow \pi^{\star}(\mathrm{bpy})\right]$ and $\left[\mathrm{d} \pi(\mathrm{Re}) \rightarrow \pi^{\star}\right.$ (alkynyl)] ${ }^{3}$ MLCT characteristics, as $\operatorname{Re}(\mathrm{CO})_{3}(\text { bpy })_{2} \mathrm{Cl}$ (bpy $=4,4$ '-bipyridine) in $\mathrm{CH}_{2} \mathrm{Cl}_{2}$ featured an emission band at $585 \mathrm{~nm}$ that originated from $\left[\mathrm{d} \pi(\mathrm{Re}) \rightarrow \pi^{\star}(\mathrm{bpy})\right]$ transition $^{19}$, with an additional luminescence in shorter wavelength at $431 \mathrm{~nm}$ (Fig. 1). For the measurement of quantum yield calculation, emission band at $619 \mathrm{~nm}$ was employed. In contrast, complexes 2 and $\mathbf{3}$ display IL luminescence at 445 and 489(sh), $521 \mathrm{~nm}$, respectively (Fig. 1, Table 1). i.e., the triplet CT Re-based excited states $\left[\mathrm{d} \pi(\mathrm{Re}) \rightarrow \pi^{\star}(\right.$ bpy) $]$ and/ or $\left[\mathrm{d} \pi(\mathrm{Re}) \rightarrow \pi^{\star}(\right.$ alkynyl)] in 2 and $\mathbf{3}$ undergo a quenching process, which can be attributed by triplet acceptors such as the naphthalene and anthracene moieties.

For excitation at any wavelength in the CT absorption region of $\mathbf{3}$, the structured emission maxima in the region $360-520 \mathrm{~nm}$ with a tail up to $700 \mathrm{~nm}$ can be observed at room temperature in steady-state emission spectra (Fig. S3). In consideration of the position, and the structured shape, the origin of these emission bands should be the luminescence of the LLCT and/or ILCT states in $\mathbf{3}$. The luminescence lifetimes for $\mathbf{2}$ and $\mathbf{3}$ are biexponential in the nanosecond time scale at room temperature, indicating the presence of two different excited states (Table 1). Hence, the observation of a small Stokes shift with short $\tau_{\text {em }}$ values in $\mathbf{2}$ and 3 indicates that emission is predominantly of ${ }^{1} \pi \rightarrow \pi^{\star}$ character. In general, the emission maximum of 1-3 is sensitive to the nature of the alkynylene ligand. Low-temperature emission spectra for alkynylene ligands and 1-3 were recorded in a THF rigid matrix at $77 \mathrm{~K}$ (Figs. S4-S6), and the data are shown in Table 1. The excitation spectra of the emission in $\mathbf{2}$ and $\mathbf{3}$ were dependent of the emission wavelength selected and closely resembled the absorption spectra over the entire spectral range (Fig. S7).

The photoluminescence lifetimes $\left(\tau_{\mathrm{em}}\right)$ and quantum yields $\left(\lambda_{\text {em }}\right)$ for 1-3 in THF solution are listed in Table 1 . The $\lambda_{\text {em }}$ and $\lambda_{\text {em }}$ values were also used to compute the radiative and nonradiative decay

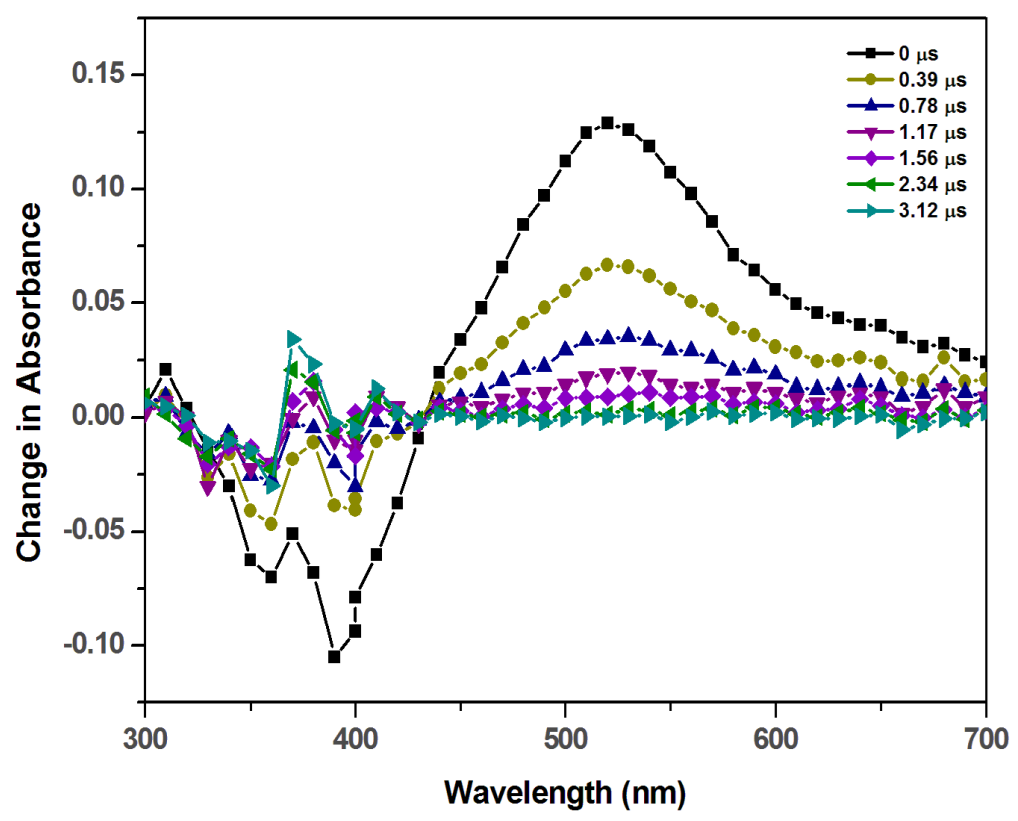

Fig. 2: Transient absorption spectra by laser-flash photolysis of 2 in degassed THF at $298 \mathrm{~K}$ within $16 \mu \mathrm{s}$ after laser excitation at $\lambda_{\mathrm{ex}}=355 \mathrm{~nm}$ on different time-scale. The Insert shows a measurement taken at $520 \mathrm{~nm}$ with a bi-exponential decay time scale $\left(\tau_{\mathrm{em}}=6.2\right.$ and $\left.0.29 \mu \mathrm{s}\right)$ and the solid line represents the exponential fitting of the data 
rate constants ( $k_{r}$ and $k_{n r}$ respectively) and these parameters are compiled in Table 1. Inspection of the data for 1-3 collected in Table 1 reveal that there are no clear trends in either the $\lambda_{\text {em }}$ or $\lambda_{\text {em }}$ values. The lack of a systematic trend in photophysical parameters for this series points out the possibility that more than one excited state contributes to the photophysics of these complexes. The most obvious among this series is the phenyl substituted complex 1 , which features a $k_{n r}$ that is nearly 20 times smaller than that of $\mathbf{2}$ and 10 times smaller than that of $\mathbf{3}$. The difference in non-radiative decay rates can be explained by the fact that the LLCT and/or ILCT states are close in energy to the MLCT states in 2 and 3 . The excited state lifetime of 2 and $\mathbf{3}$ is increased slightly, compared to the free ligands bpen and bpea, respectively. This study also supports that part of the energy from the triplet donors, i.e., $\left[\mathrm{d} \pi(\mathrm{Re}) \rightarrow \pi^{\star}(\mathrm{bpy})\right]$ and/or $\left[\mathrm{d} \pi(\mathrm{Re}) \rightarrow \pi^{\star}(\right.$ alkynyl) $]$ chromophores, is transferred to triplet acceptors such as the naphthalene and anthracene moieties. The rate constant for energy transfer to the napthyl and anthryl units of $\mathbf{2}$ and $\mathbf{3}$, respectively can be obtained using eq 1.

$$
k_{e n}=1 / \tau_{\mathrm{em}}-1 / \tau_{\mathrm{em}(0)}
$$

where $\tau_{\mathrm{em}}$ and $\tau_{\mathrm{em}(\mathrm{o})}$ are the emission lifetime of $\mathbf{2}$ and $\mathbf{3}$ and model compound 1, respectively. Based on our observations, the energy transfer rate constants are $7.8^{\prime} 10^{7} \mathrm{~s}^{-1}$ for 2 and $3.3^{\prime} 10^{7} \mathrm{~s}^{1}$ for 3 . Additional support for the sensitization of the ${ }^{3}$ LLCT and/or ${ }^{3}$ ILCT states of $\mathbf{2}$ and $\mathbf{3}$ comes from transient absorption measurements.

\section{Time-Resolved Absorption Spectra}

By using nanosecond time-resolved spectroscopic techniques, insight can be gained into the excited state properties responsible for the photoinduced behavior of rectangles 1-3. The transient absorption (TA) spectrum of 1 exhibits a bleaching of the two MLCT absorptions in the region from 330 to $380 \mathrm{~nm}$. In addition, this complex shows a broad and much stronger positive

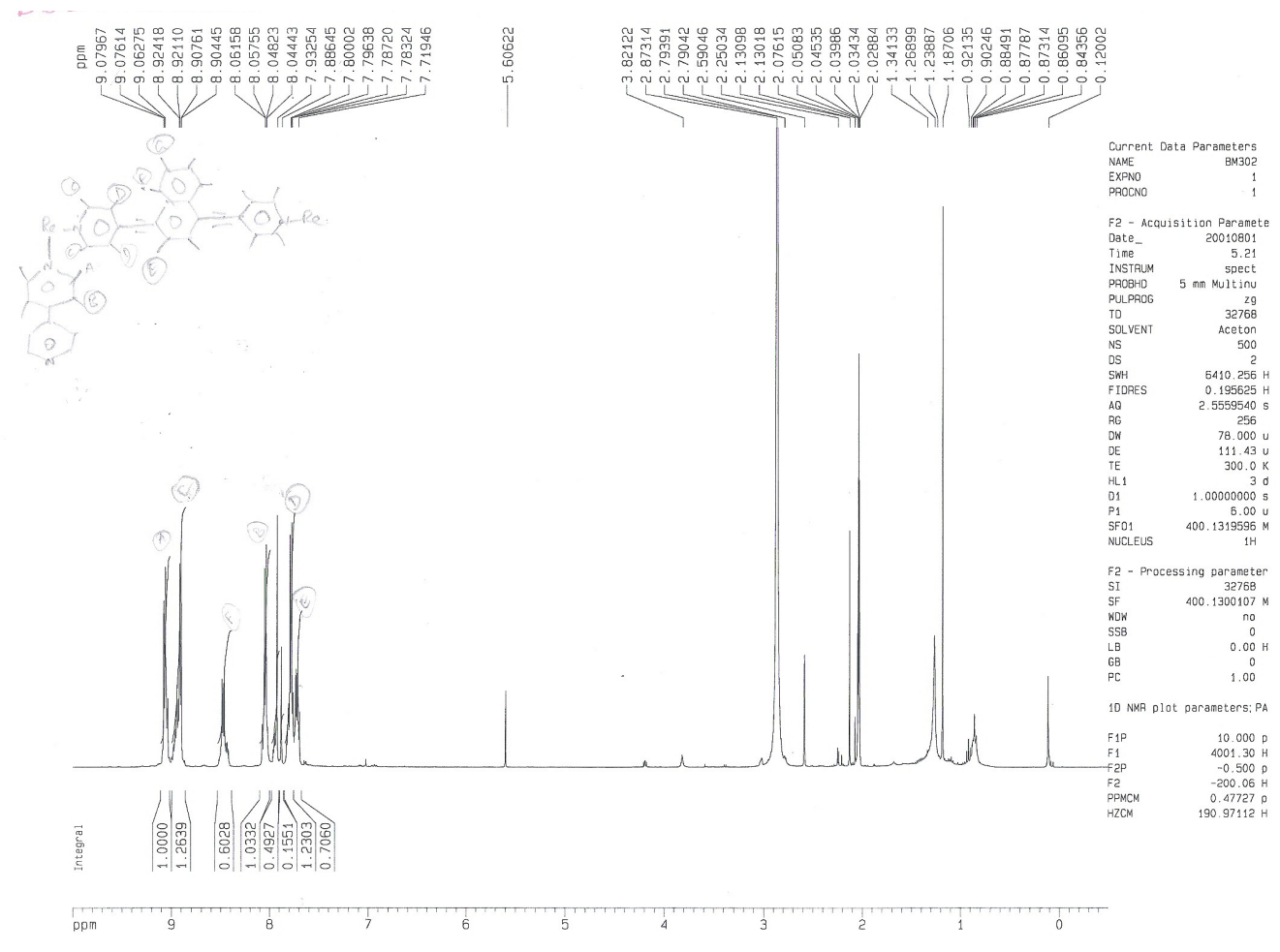

Fig. S1. ${ }^{1} \mathrm{H}$ NMR (400 MHz) spectrum of compound 2 in acetone- $d_{6}$. Inset shows the expansion of aromatic region of 2 
absorption at 420-700 nm (Fig. S8). The decay of the red absorption region is mono-exponential with a lifetime about $0.320 \mu \mathrm{s}$, and the agreement with the emission lifetime of the low energy band in Fig. 1 suggests that they originate from the $[d \pi(R e)$ $\left.\rightarrow \pi^{\star}(\mathrm{bpy})\right]$ and/or $\left[\mathrm{d} \pi(\mathrm{Re}) \rightarrow \pi^{*}\left(\right.\right.$ alkynyl) ${ }^{3} \mathrm{MLCT}$ excited states. Laser flash excitation of 2 at 355 $\mathrm{nm}$ leads to a structured bleaching of the MLCT absorption in the region from 330 to $430 \mathrm{~nm}$ with a maximum at $380 \mathrm{~nm}$ during triplet population ${ }^{32,33}$. In addition, this complex showed a broad and much stronger positive absorption at 450-700 nm (Fig. 2). The decay of the TA region is bi-exponential with a lifetime of $\tau_{1}=0.62 \mathrm{~ms}$ and $\tau_{2}=0.29 \mathrm{~ms}$ for 2 . Since the free bpen alkynyl ligand also showed a stronger positive absorption at $480 \mathrm{~nm}$ with a decay of $0.85 \mu \mathrm{s}$ (Fig. S9), we believe that the excited state decay of $\mathbf{2}$ originates from the different states, i.e., ${ }^{3}$ LLCT/3ILCT excited states. The transient absorption (TA) spectrum of 3 exhibits a bleaching of the MLCT absorption in the region from 420 to $480 \mathrm{~nm}$ with a maximum at $460 \mathrm{~nm}$ during triplet population ${ }^{32,33}$. In addition, this complex shows a broad and much stronger positive absorption at 500-700 nm (Fig. S10). The decay of absorbing triplet excited state is also bi-exponential with a lifetime of $2.44 \mu$ s and $\tau_{2}=0.011 \mu \mathrm{s}$ for 3 , which is not in agreement with the emission lifetime of the low energy band in Fig. 1 suggests that they originate from different excited states. Compared with the steady-state emission spectra of $\mathbf{2}$ and $\mathbf{3}$, the longer wavelength positive absorption band at $450-700 \mathrm{~nm}$ provides direct evidence for the existence of another excited state. The much longer lifetime for this band $\left(\tau_{1}=0.62 \mathrm{~ms}\right.$ and $\tau_{2}=0.29 \mathrm{~ms}$ for 2 and $2.44 \mu \mathrm{s}$ and $\tau_{2}=0.011$ $\mu$ s for 3 ) excludes the possibility of ${ }^{1}$ LLCT and ${ }^{1}$ ILCT excited states. The appropriate assignment for this triplet excited-state decays of $\mathbf{2}$ and $\mathbf{3}$ should be the ${ }^{3} \mathrm{LLCT}$ and ${ }^{3} \mathrm{LL}$ excited states.

Several studies have reported triplet energy transfer from a metal ion center to an aryl hydrocarbon, ${ }^{32-36}$ but, in some cases, the photosystems were unstable with respect to the sensitized oxygenation of the polycycle ${ }^{36}$. Meyer and co-workers ${ }^{37}$ reported an intense transient absorption at $450600 \mathrm{~nm}$, which is characteristic of a 4,4'-bpylocalized MLCT excited state in $\operatorname{Re}(\mathrm{I})$ complexes. Castellano and co-workers ${ }^{38}$ postulated that one could potentially observe significantly extended

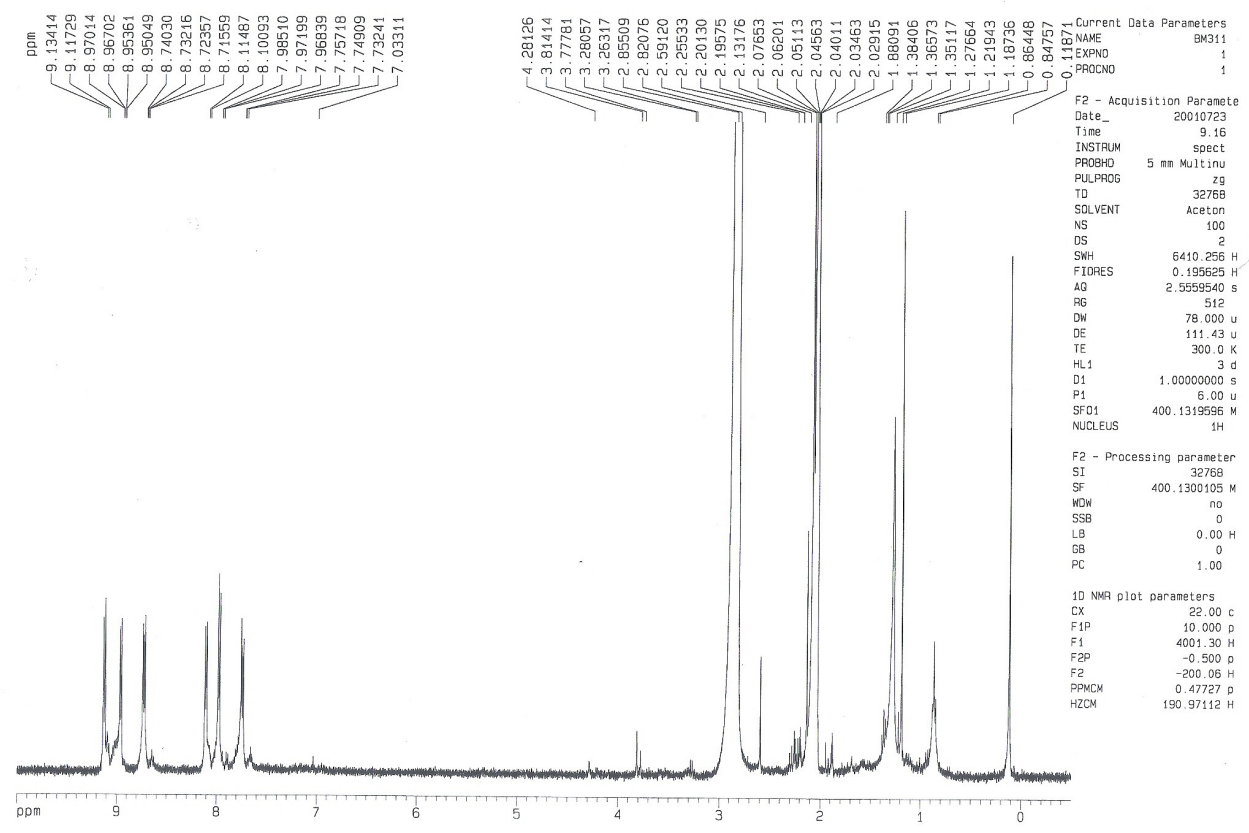

Fig. S2. ${ }^{1} \mathrm{H}$ NMR (400 MHz) spectrum of compound 3 in acetone- $d_{6}$. Inset shows the expansion of aromatic region of 3 
lifetimes in metal complexes if the appropriate chromophores are appended as alkynyl ligands. A detailed study by the Keller and Schanze ${ }^{39}$ also demonstrated that the ${ }^{3} \mathrm{LC}$ states of alkynyl ligands can markedly influence the excited state decay. Given these facts, the TA band of 2 and $\mathbf{3}$ can not be assigned to the transient absorption of the pure ${ }^{3} \mathrm{MLCT}$ excited states. The lower region observed at 450-700 nm for 2 and 3 might be expected to be due to the longer lived ligand localized states of alkynyl ligands ${ }^{40-43}$. Hence the prolonged lifetimes observed for $\mathbf{2}$ and $\mathbf{3}$ might be due to the triplet state localized on the $\mathrm{Re}(\mathrm{I})$ chromophores being in equilibrium with the triplet states associated with the ${ }^{3} \mathrm{LLCT}$ and ${ }^{3} \mathrm{IL}$ excited states. This prompts us to propose that the difference in the ${ }^{3} \mathrm{MLCT}$ energies of 1-3 may be smaller than the energy difference between ${ }^{3} \mathrm{MLCT}$ states and ${ }^{3} \mathrm{LC}$ states.

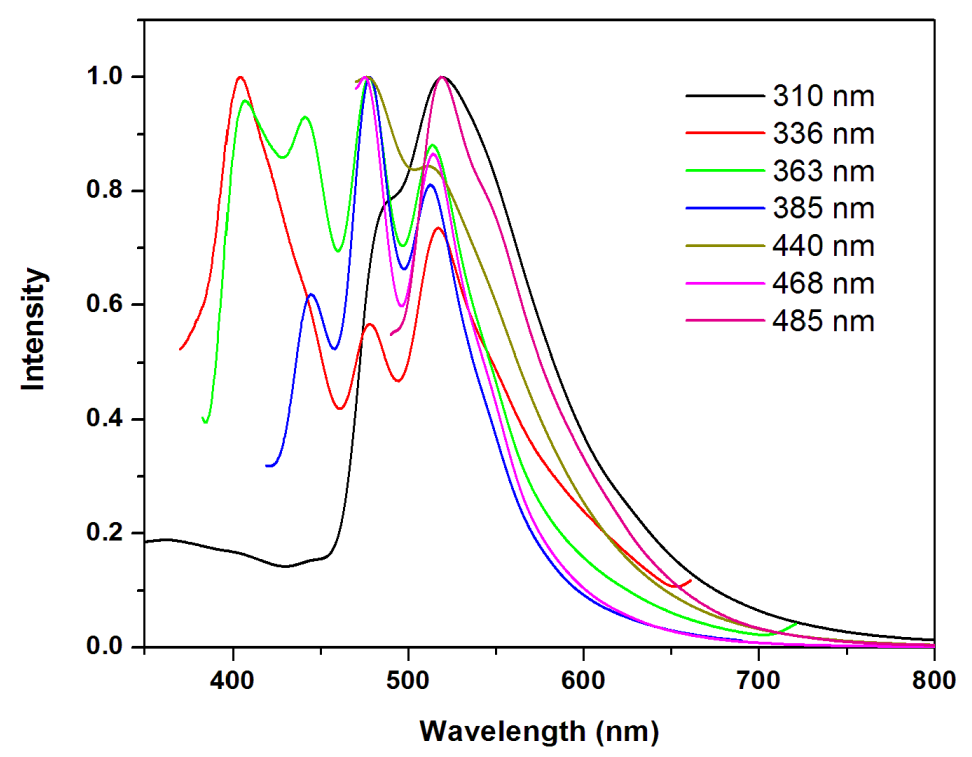

Fig. S3. Emission spectra of 3 in THF at different wavelength excitation

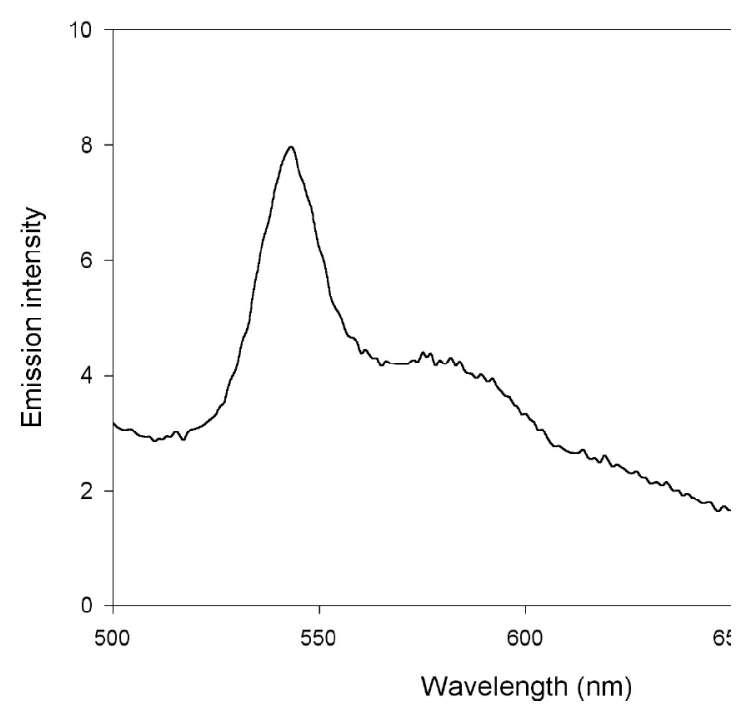

Fig. S4. Emission spectrum of 1 in THF at $77 \mathrm{~K}\left(\lambda_{\mathrm{ex}}=360 \mathrm{~nm}\right)$ 
Since the distance from $\operatorname{Re}(\mathrm{I})$ component to naphthalene/anthracene unit is less than $1 \mathrm{~nm}$ the most probable mechanism for energy transfer is Dexter mechanism ${ }^{44}$. In addition, the presence of short lifetime observed by the time-correlated single photon counting technique excludes the Forster mechanism ${ }^{45}$ as a candidate for the energy transfer mechanism. However, at this stage it is premature to rule out operation of Förster mechanism here and the system will be further studied in order to understand the mechanism clearly. Therefore, it is tentatively assigned that some portion of the excitation light absorbed by the $\operatorname{Re}(\mathrm{I})$ chromophore in $\mathbf{2}$ and $\mathbf{3}$ is first transferred to the alkynyl ligand ( ${ }^{2} \mathrm{LC}$ state) and is subsequently redistributed between the luminescent ${ }^{3}$ LLCT and ${ }^{3} \mathrm{LL}$ excited states and ${ }^{3} \mathrm{MLCT}$ potential levels (Scheme 1). According to this scenario, in the case of $\mathbf{2}$ and $\mathbf{3}$, the overall excitation energy

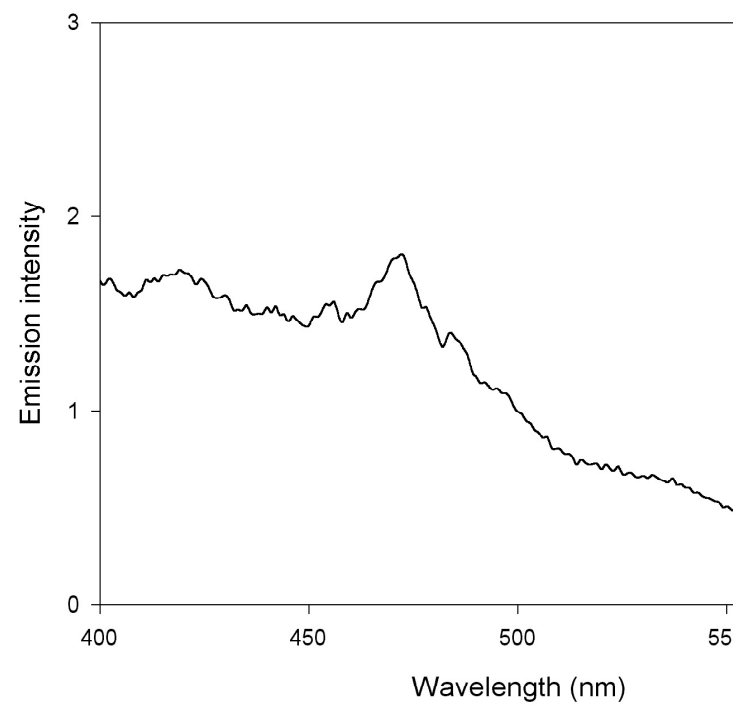

Fig. S5. Emission spectrum of 2 in THF at $77 \mathrm{~K}\left(\lambda_{\mathrm{ex}}=380 \mathrm{~nm}\right)$

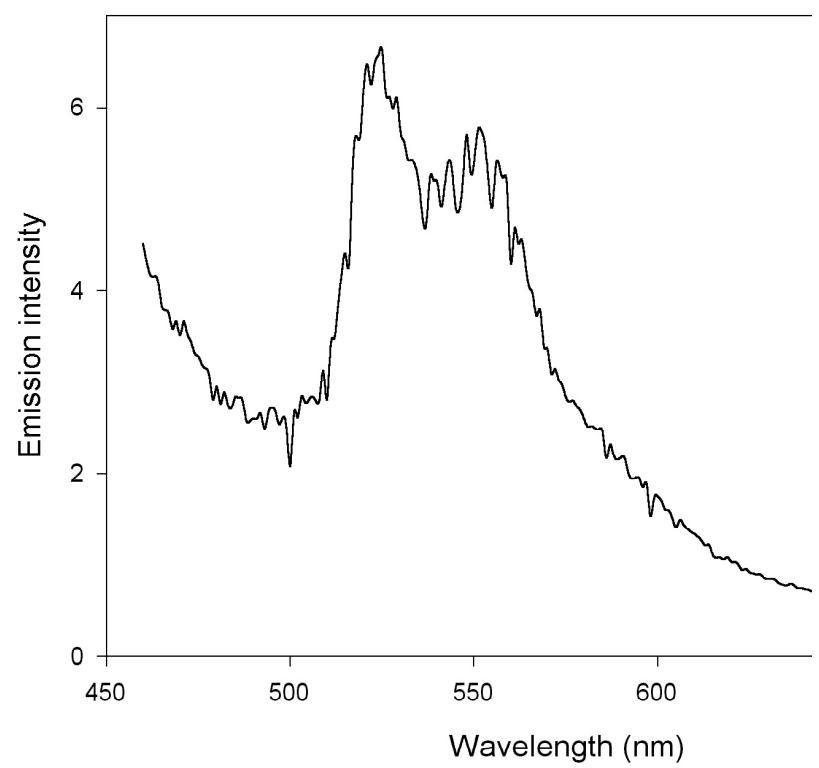

Fig. S6. Emission spectrum of 3 in THF at $77 \mathrm{~K}\left(\lambda_{\mathrm{ex}}=380 \mathrm{~nm}\right)$ 
collection process includes an indirect, two step $\mathrm{Re} \rightarrow$ alkynyl ligand energy transfer, which is mediated by a spatially interposed alkynylene unit in a manner such that the ${ }^{3} \mathrm{LLCT}$ and ${ }^{3} \mathrm{LL}$ energy levels act as a reservoir for the excitation energy. Thus, it was observed that the variation of the substituents

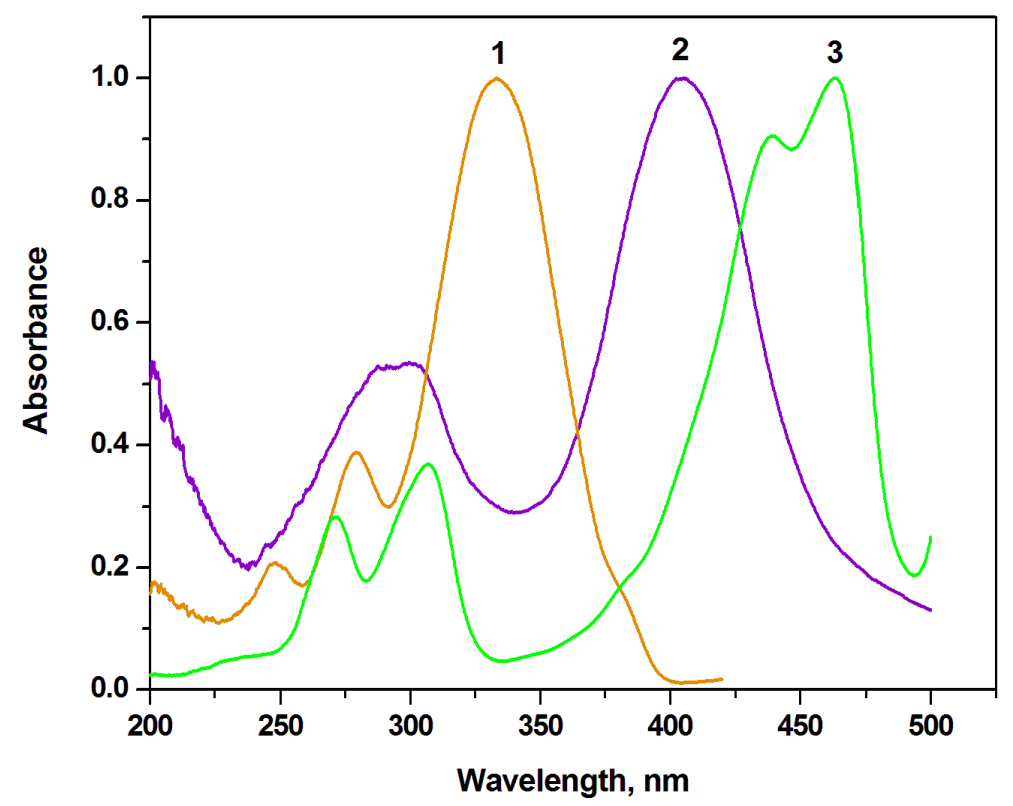

Fig. S7. Excitation spectra obtained by using (a) $\lambda_{\mathrm{em}}=619 \mathrm{~nm}$ for 1 , (b) $530 \mathrm{~nm}$ for 2 and (c) $532 \mathrm{~nm}$ for $3 \mathrm{in} \mathrm{THF}$ at $298 \mathrm{~K}$

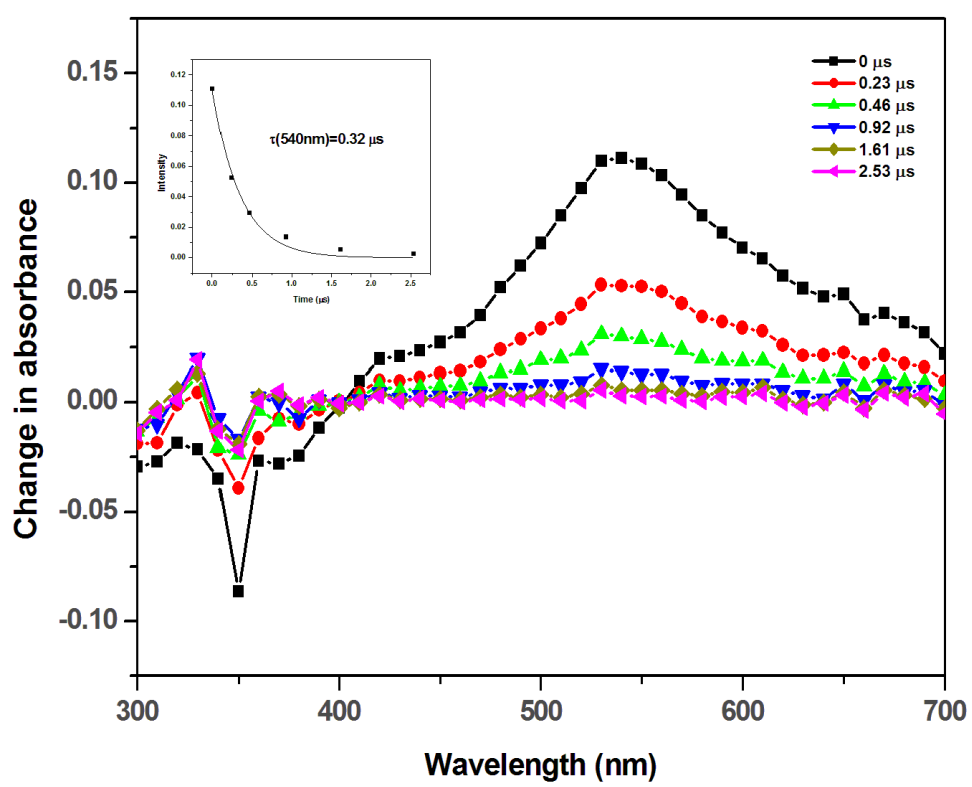

Fig. S8: Transient absorption spectra by laser-flash photolysis of 1 in degassed THF at $298 \mathrm{~K}$ within $4 \mathrm{~ms}$ after laser excitation at $\lambda_{\mathrm{ex}}=355 \mathrm{~nm}$ in different time-scale. The bleaching at $350 \mathrm{~nm}$ is due to scattering of the laser light. Insert shows a measurement taken at $540 \mathrm{~nm}$ with a decay time scale $(\tau=0.32 \mathrm{~ms}$ ) and the solid line represents the exponential fitting of the data 


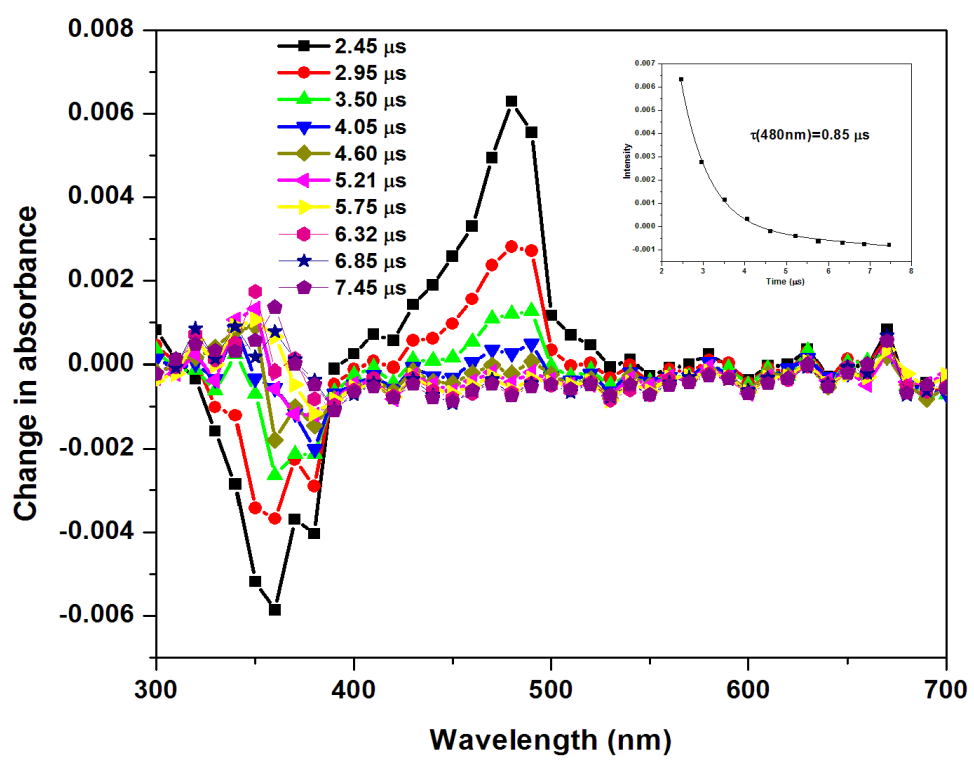

Fig. S9: Transient absorption spectra by laser-flash photolysis of bpen in degassed THF at $298 \mathrm{~K}$ at $8 \mu$ s after laser excitation at $\lambda_{\text {ex }}=355 \mathrm{~nm}$ on different time-scale. The ground-state absorption was 0.7 at the excitation wavelength. Insert shows a measurement taken at $480 \mathrm{~nm}$ with a decay time scale $(\tau=0.85 \mathrm{~ms}$ ) and the solid line represents the exponential fitting of the data

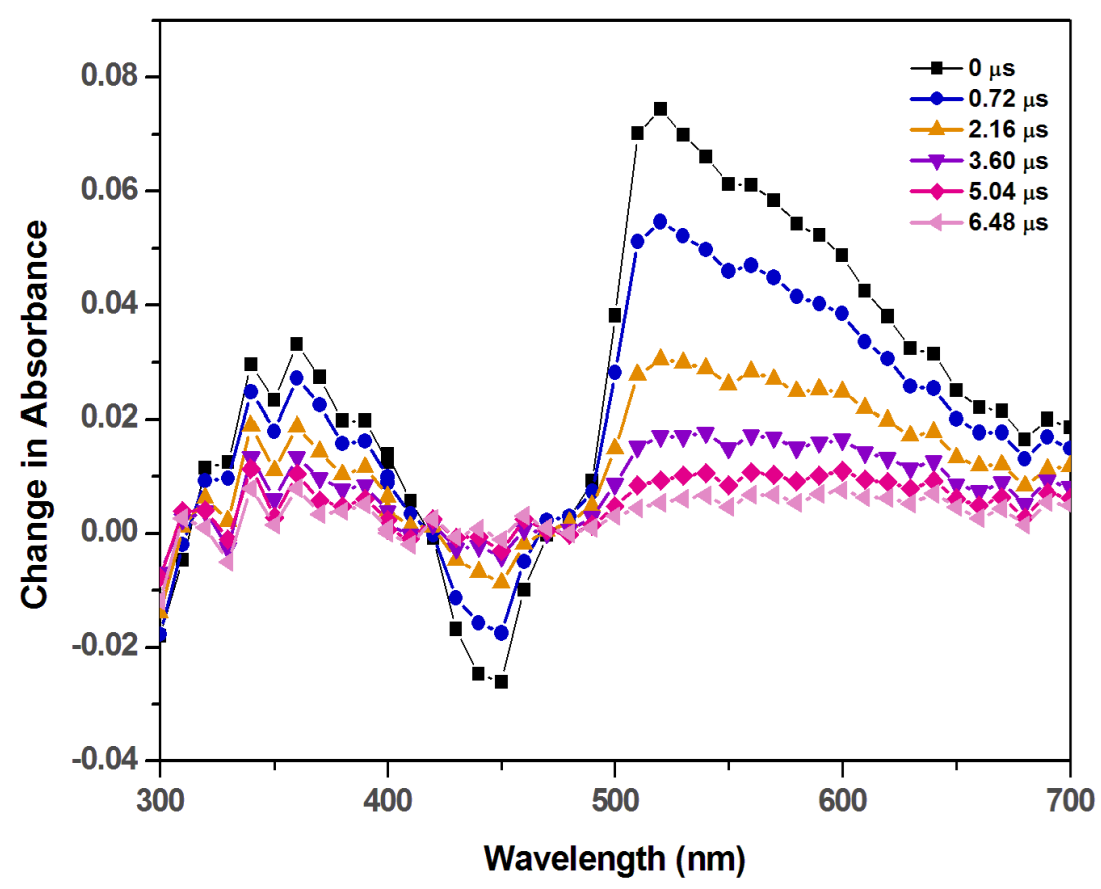

Fig. S10: Transient absorption spectra by laser-flash photolysis of 3 in degassed THF at 298 $\mathrm{K}$ within $8 \mu \mathrm{s}$ after laser excitation at $\lambda_{\mathrm{ex}}=355 \mathrm{~nm}$ on different time-scale. The Insert shows a measurement taken at $520 \mathrm{~nm}$ with a bi-exponential decay time scale $\left(\lambda_{\mathrm{em}}=2.44\right.$ and $\left.0.011 \mu \mathrm{s}\right)$ and the solid line represents the exponential fitting of the data 
on the alkynyl ligands enable the fine tuning of the emission energy, which would be exceptionally important in the realization of supramolecular electron- and energy-transfer systems.

\section{CONCLUSION}

In summary, molecular rectangles are shown, for the first time, to mimic the natural photosynthetic chromophores. Successful emission color tuning is achieved by incorporating rigid alkynyl ligands into 1-3. The blue shift in emission maximum upon extending the $\pi$-conjugated system in these complexes represents an unusual phenomenon. Complex 1 which is bridged by a phenyl unit, exhibits a typical strong ${ }^{3} \mathrm{MLCT}$ luminescence behavior while compounds $\mathbf{2}$ and $\mathbf{3}$ show IL luminescence through energy transfer process. Thus, the variation of the substituents on the alkynyl ligands enabled the fine tuning of the emission energy of 1-3. Future research along these lines would also involve the integration of these artificial antennae into electron/energy transfer relay systems to achieve artificial photosynthesis.

\section{ACKNOWLEDGEMENTS}

We thank Council of Scientific and Industrial Research (CSIR), New Delhi for financial support in the form of a project. Prof. S.R thanks UGC, New Delhi for sanctioning UGC-BSR Faculty and UGC Emeritus Fellowships. P.T thanks Academia Sinica and the National Science Council of Taiwan for financial support. A.R is the recipient of UGC Meritorious fellowship under the Basic Scientific Research (BSR) Scheme.

\section{REFERENCES}

1. Kuhlbrandt, W. Many wheels make light work. Nature, 1995, 374, 497-498.

2. Hu, X.; Damjanovic, A.; Ritz, T.; Schulten, $\mathrm{K}$. Architecture and mechanism of the lightharvesting apparatus of purple bacteria. Proc. Natl. Acad. Sci. U.S.A., 1998, 95, 5935 5941.

3. Frischmann, P. D.; Mahata, K.; Wurthner, F. Powering the future of molecular artificial photosynthesis with light-harvesting metallosupramolecular dye assemblies. Chem. Soc. Rev., 2013, 42, 1847-1870.

4. Jalal, K.C.A.; Zaima Azira, Z.A.; Nor Hafizah, Z.; Rahman, M. M.; Kamaruzzaman, B.Y.; Noor Faizul, H. N. Carotenoid contents in anoxygenic phototrophic purple bacteria, marichromatium sp. and rhodopseudomonas sp. of tropical aquatic environment, Malaysia. Orient. J. Chem., 2014, 30, 607-613.

5. Cooke, M. W.; Hanan, G. S.; Loiseau, F.; Campagna, S.; Watanabe, M.; Tanaka, Y. The structural and functional roles of rhodium(II)-rhodium(II) dimers in multinuclear ruthenium(II) complexes. Angew. Chem. Int. Ed., 2005, 44, 4881-4884.

6. E. Baranoff, J.-P. Collin, L. Flamigni, J.-P. Sauvage, From ruthenium(II) to iridium(III): 15 years of triads based on bis-terpyridine complexes. Chem. Soc. Rev., 2004, 33, 147 -
155.

7. Uthayanila, S.; Neeraja, P. Synthesis, characterization and in-vitro cytotoxic studies of $5,10,15,20$ - tetra pyridyl porphyrin coordinated to four [Ru (bipy) $\left.{ }_{2} \mathrm{Cl}\right]^{+}$groups. Orient. J. Chem., 2015, 31, 867-673.

8. Splan, K. E.; Massari, A. M.; Morris, G. A.; Sun, S.-S.; Reina, E.; Nguyen, S. T.; Hupp, J.T. Photophysical and energy-transfer properties of (salen)zinc complexes and supramolecular assemblies. Eur. J. Inorg. Chem., 2003, 23482351.

9. Splan, K. E.; Keefe, M. H.; Massari, A M.; Walters, K. A.; Hupp, J. T. Synthesis, characterization, and preliminary intramolecular energy transfer studies of rigid, emissive, rhenium-linked porphyrin dimers. Inorg. Chem., 2002, 41, 619-621.

10. Sautter, A.; Kaletas, B. K.; D. G. Schmid, R. Dobrawa, M. Zimine, G. Jung, I. H. M. van Stokkum, L. De Cola, R. M. Williams, F. Wurthner, Ultrafast energy-electron transfer cascade in a multichromophoric lightharvesting molecular square. J. Am. Chem. Soc., 2005, 127, 6719-6729.

11. Tang, M.-C.; Tsang, D. P.-K.; Wong, Y.-C.; Chan, M.-Y.; Wong, K.M.-C.; Yam, V.W.-W. Bipolar gold(III) complexes for solutionprocessable organic light-emitting devices 
with a small efficiency roll-off. J. Am. Chem. Soc., 2014, 136, 17861-17868.

12. Yu, S.; Zeng, Y.; Chen, J.; Yu, T.; Zhang, X.; Yang, G.; Li, Y. Intramolecular triplet-triplet energy transfer enhanced triplet-triplet annihilation upconversion with a short-lived triplet state platinum(II) terpyridyl acetylide photosensitizer. RSC Adv., 2015, 5, 7064070648.

13. Hung, L.-L.; Lam, W. H.; Wong, K.M.-C.; Cheng, E.C.-C.; Zhu, N.; Yam, V.W.-W. Synthesis, luminescence and electrochemical properties of luminescent dinuclear mixedvalence gold complexes with alkynyl bridges. Inorg. Chem. Front., 2015, 2, 453-466.

14. Chan, A.K.-W.; Wong, K.M.-C.; Yam, V.W.-W. Supramolecular assembly of isocyanorhodium(I) complexes: An interplay of rhodium(I)...rhodium(I) interactions, hydrophobic-hydrophobic interactions, and host-guest chemistry. J. Am. Chem. Soc., 2015, 137, 6920-6931.

15. Lam, S.-T.;Wang, G.;Yam, V.W.-W.Luminescent metallogels of alkynylrhenium(I) tricarbonyl diimine complexes. Organometallics, 2008, 27, 4545-4548.

16. Lin, J. T.; Sun, S.-S.; Wu, J .J.; Lee, L.; Lin, K.-J.; Huang, Y. F. Dinuclear metal carbonyls bridged by pyridyl ligands incorporating an alkyne entity. Inorg. Chem. 1995, 34, 23232333.

17. Ciana, L. D.; Haim, A. Synthesis of 1,4-bis(4pyridyl)butadiyne. J. Heterocycl. Chem., 1984, 21, 607-608.

18. Champness, N. R.; Khlobystov, A.N.; Majuga, A. G.; Schroder, M.; Zyk, N. V. An improved preparation of 4-ethynylpyridine and its application to the synthesis of linear bipyridyl ligands. Tetrahedron Lett., 1999, 40, 54135416.

19. Rajendran, T.; Manimaran, B.; Liao, R.-T.; Lin, R.-J.; Thanasekaran, P.; Lee, G.-H.; Peng, S.-M.; Liu, Y.-H.; Chang, I.-J.; Rajagopal, S.; Lu, K.-L. Synthesis and photophysical properties of neutral luminescent rheniumbased molecular rectangles. Inorg. Chem., 2003, 42, 6388-6394.

20. Rajendran, T.; Manimaran, B.; Liao, R.-T.; Liu, Y.-H.; Thanasekaran, P.; Lin, R.-J.; Chang, I.-J.; Chou, P.-T.; Ramaraj, R.; Rajagopal,
S.; Lu, K.-L. Luminescence quenching of_Re(I)_molecular rectangles by quinones. Dalton Trans., 2010, 39, 2928-2935.

21. Wu, P.-C.; Yu, J.-K.; Song, Y.-H.; Chi, Y.; Chou, P.-T.; Peng, S.-M.; Lee, G.-H. Synthesis and characterization of metal complexes possessing the 5-(2-pyridyl) pyrazolate ligands: The observation of remarkable osmium-induced blue phosphorescence in solution at room temperature. Organometallics, 2003, 22, 4938-4946.

22. Rajendran, T.; Manimaran, B.; Lee, F.-Y.; Lee, G.-H.; Peng, S.-M.;Wang, C. M.; Lu, K.-L. First light-emitting neutral molecular rectangles. Inorg. Chem. 2000, 39, 2016-2017.

23. Chung, W.-K.; Wong, K.M.-C.; Lam, W. H.; Zhu, X.; Zhu, N.; Kwok, H.-S.; Yam, V.W.-W. Syntheses, photophysical, electroluminescence and computational studies of rhenium(I) diimine triarylaminecontaining alkynyl complexes. New J. Chem. 2013, 37, 1753-1767.

24. Yam, V.W.-W.; Chong, S.H.-F.; Ko, C.-C.; Cheung, K.-K. Synthesis and luminescence behavior of rhenium(I) triynyl complexes. X-ray crystal structures of $\left[\operatorname{Re}(\mathrm{CO})_{3}\left({ }^{\mathrm{t}} \mathrm{Bu} \mathrm{u}_{2} \mathrm{bpy}\right)\right.$ (C:C-C:C-C:CPh] and $\left[\operatorname{Re}(\mathrm{CO})_{3}\left(\mathrm{Me}_{2} \mathrm{bpy}\right)\right.$ (C:C-C:C-C:CSiMe ${ }_{3}$. Organometallics, 2000, 19, 5092-5097.

25. Lam, S.-T.; Zhu, N.; Au, V.K.-M.; Yam, V.W.-W. Synthesis, characterization, electrochemistry and photophysical studies of rhenium(I) tricarbonyl diimine complexes with carboxaldehyde alkynyl ligands. Polyhedron, 2015, 86, 10-16.

26. Li, M.-J.; Kwok, W.-M.; Lam, W. H.; Tao, C.-H.; Yam, V.W.-W.; Phillips, D. L. Synthesis of coumarin-appended pyridyl tricarbonylrhenium(I) 2,22 -bipyridyl complexes with oligoether spacer and their fluorescence resonance energy transfer studies. Organometallics, 2009, 28, 16201630.

27. Sun, S.-S.; Lees, A. J. Synthesis and photophysical properties of dinuclear organometallic rhenium(I) diimine complexes linked by pyridine-containing macrocyclic phenylacetylene ligands. Organometallics, 2001, 20, 2353-2358.

28. Li, Z.; Sun, W. Synthesis, photophysics, and 
reverse saturable absorption of platinum complexes bearing extended 0-conjugated $\mathrm{C}^{\wedge} \mathrm{N}^{\wedge} \mathrm{N}$ ligands. Dalton Trans., 2013, 42, 14021-14029.

29. Winter, A.; Friebe, C.; Chiper, M.; Schubert, U. S.; Presselt, M.; Dietzek, B.; Schmitt, M.; Popp, J. Synthesis, characterization, and electro-optical properties of $\mathrm{Zn}^{\text {"I_complexes }}$ with ठ-conjugated terpyridine ligands. ChemPhysChem, 2009, 10, 787-798.

30. Grosshenny, V.; Harriman, A.; Romero, F. M.; Ziessel, R. Electron delocalization in ruthenium(II) and osmium(II) 2,2'-bipyridyl complexes formed from ethynyl-bridged ditopic ligands. J. Phys. Chem., 1996, 100, 17472-17484.

31. Maubert, B.; McClenaghan, N. D.; Indelli, M. T.; Campagna, S. Absorption spectra and photophysical properties of a series of polypyridine ligands containing appended pyrenyl and anthryl chromophores and of their ruthenium(II) and osmium(II) complexes. J. Phys. Chem. A, 2003, 107, 447-455.

32. El-ghayoury, A.; Harriman, A.; Khatyr, A.; Ziessel, R. Intramolecular triplet energy transfer in metal polypyridine complexes bearing ethynylated aromatic groups. J. Phys. Chem. A, 2000, 104, 1512-1523.

33. Sathish, V.; Babu, E.; Ramdass, A.; Lu, Z.-Z.; Chang, T.T.; Velayudham, M.; Thanasekaran, P.; Lu, K.-L.; Li, W.-S.; Rajagopal, S. Photoswitchable alkoxy-bridged binuclear rhenium(I) complexes - a potential probe for biomolecules and optical cell imaging. $R S C$ Adv., 2013, 3, 18557-18566.

34. Barigelletti, F.; Flamigni, L. Photoactive molecular wires based on metal complexes. Chem. Soc. Rev., 2000, 29, 1-12.

35. El-ghayoury, A.; Harriman, A.; Ziessel, R. Intercompartmental electron exchange in geometrically-constrained Ru"Os triads built around diethynylated aryl hydrocarbons. J. Phys. Chem. A, 2000, 104, 7906-7915.

36. Belser, P.; Dux, R.; Baak, M.; De Cola, L.; Balzani, V. Electronic energy transfer in a supramolecular species containing the $\left[\mathrm{Ru}(\mathrm{bpy})_{3}\right]^{2+},\left[\mathrm{Os}(\mathrm{bpy})_{3}\right]^{2+}$, and anthracene chromophoric units Angew. Chem. Int. Ed. Engl., 1995, 34, 595-598.

37. Tapolsky, G.; Duesing, R.; Meyer, T. J. Intramolecular energy transfer by an electron/ energy transfer cascade. J. Phys. Chem., 1989, 93, 3885-3887.

38. Hua, F.; Kinayyigit, S.; Rachford, A.A.; Shikhova, E. A.; Goeb, S.; Cable, J. R.; Adams, C. J.; Kirschbaum, K.; Pinkerton, A. A.; Castellano, F. N. Luminescent chargetransfer platinum(II) metallacycle. Inorg. Chem., 2007, 46, 8771-8783.

39. Keller, J. M.; Schanze, K. S. Synthesis of monodisperse platinum acetylide oligomers end-capped with naphthalene diimide units. Organometallics, 2009, 28, 4210-4216.

40. Ziessel, R. F. Photo-induced energy or electron transfer in supramolecular systems: Applications to molecular wires and lightharvesting sensors. J. Chem. Edu., 1997, 74, 673-679.

41. Otsuki, J.; Imai, A.; Sato, K.; Li, D.-M.; Hosoda, M.; Owa, M.; Akasaka, T.;Yoshikawa, I.; Araki, K.; Suenobu, T.; Fukuzumi, S. Switchable Antenna: A star-shaped ruthenium/osmium tetranuclear complex with azobis(bipyridine) bridging ligands. Chem. -Eur. J., 2008, 14, 2709-2718.

42. Welter, S.; Lafolet, F.; Cecchetto, E.; Vergeer, F.; De Cola, L. Energy transfer by a hopping mechanism in dinuclear Irll/Rull complexes: A molecular wire?. ChemPhysChem, 2005, 6, 2417-2427.

43. Ichimura, K.; Kobayashi, T.; King, K. A.; Watts, R. J. Excited-state absorption spectroscopy of ortho-metalated iridium(III) complexes. J. Phys. Chem. 1987, 91, 6104-6106.

44. Dexter, D. L. A theory of sensitized luminescence in solids. J. Chem. Phys., 1953, 21, 836-850.

45. Forster, T. 10th spiers memorial lecture. Transfer mechanisms of electronic excitation. Discuss. Faraday Soc., 1959, 27, 7-17. 